\title{
Cytotoxicity, nitric oxide and acetylcholinesterase inhibitory activity of three limonoids isolated from Trichilia welwitschii (Meliaceae)
}

Jean P. Dzoyem ${ }^{1,2^{*}} \mathbb{D}$, Armelle T. Tsamo ${ }^{3}$, Raduis Melong ${ }^{3}$, Pierre Mkounga ${ }^{3}$, Augustin E. Nkengfack ${ }^{3}$, Lyndy J. McGaw ${ }^{1}$ and Jacobus N. Eloff ${ }^{1}$

\begin{abstract}
Background: Limonoids are highly oxygenated compounds with a prototypical structure. Their occurrence in the plant kingdom is mainly confined to plant families of Meliaceae and Rutaceae. Owing to their wide range of pharmacological and therapeutic properties, this study was aimed at investigating the potential nitric oxide (NO) and acetylcholinesterase (AChE) inhibitory activity and the cytotoxicity of three limonoids: trichilia lactone D5 (1), rohituka 3 (2) and dregeanin DM4 (3), isolated from Trichilia welwitschii C.DC.

Results: Results indicated that the three limonoids had low cytotoxicity towards Vero cells with $\mathrm{LC}_{50}$ values ranging from 89.17 to $75.82 \mu \mathrm{g} / \mathrm{mL}$. Compounds (2) and (3) had lower cytotoxicity compared to puromycin and doxorubicin used as reference cytotoxic compounds. Compound $(\mathbf{1})\left(\mathrm{LC}_{50}\right.$ of $\left.23.55 \mu \mathrm{g} / \mathrm{mL}\right)$ had good antiproliferative activity against RAW 264.7 cancer cells. At the lowest concentration tested $(0.5 \mu \mathrm{g} / \mathrm{mL})$, compound $(\mathbf{2})$ and $(\mathbf{3})$ released the lowest amount of nitric oxide (2.97 and $2.93 \mu \mathrm{M}$, respectively). The three limonoids had anti-AChE activity with $\mathrm{IC}_{50}$ values ranged of $19.13 \mu \mathrm{g} / \mathrm{mL}$ for $(\mathbf{1}), 34.15 \mu \mathrm{g} / \mathrm{mL}$ for $(\mathbf{2})$ and $45.66 \mu \mathrm{g} / \mathrm{mL}$ for $(\mathbf{3})$, compared to galantamine $\left({ }^{\prime} C_{50}\right.$ of $8.22 \mu \mathrm{g} / \mathrm{mL}$ ) used as positive control.

Conclusion: The limonoid compounds studied in this work inhibited nitric oxide production in LPS-stimulated macrophages and had anti-AChE activity. Trichilia lactone D5 had potential antiproliferative activity against RAW 264.7 cancer cells. The limonoids had low cytotoxicity towards Vero cells lines. This study provided further examples of the importance of limonoids compounds as potential AChE inhibitors and anti-inflammatory agents targeting the inhibition of NO production.
\end{abstract}

Keywords: Trichilia welwitschii, Cytotoxicity, Acetylcholinesterase, Nitric oxide, Limonoids

\section{Background}

Nitric oxide (NO) is an important pro-inflammatory mediator involved in a wide variety of physiological and pathophysiological events; however overproduction of NO by inducible nitric oxide synthase (iNOS) results in severe inflammation [1]. An association between the development of cancer and inflammation has long-been documented [2]. Moreover, inflammation accelerates the appearance of some neurodegenerative disorders, such as Parkinson and Alzheimer's diseases [3]. These insights are fostering new anti-inflammatory therapeutic approaches to cancer and neurodegenerative diseases development. There is no doubt that natural products remain important sources of new pharmaceutical

\footnotetext{
*Correspondence: jpdzoyem@yahoo.fr

${ }^{2}$ Department of Biochemistry, Faculty of Science, University of Dschang,

P.O. Box 67, Dschang, Cameroon

Full list of author information is available at the end of the article
} 
compounds. Therefore, natural products research continues to explore a variety of compounds which may be used for the development of new drugs.

Limonoids are highly oxygenated compound with a prototypical structure, either containing or derived from a precursor with a 4,4,8-trimethyl-17-furanylsteroid skeleton. The prototypical structure consists of four six-membered rings and a furan ring. It is an important group of metabolically altered triterpenes, which are limited in their distribution. Their occurrence in the plant kingdom is mainly confined to plant families of Meliaceae and Rutaceae, and occurs less frequently in Cneoraceae and Harrisonia sp. of Simaroubaceae [4]. Limonoids isolated from the plant family Meliaceae are more complex with very high degree of oxidation and structural rearrangements [5]. In recent years a large number of pharmacological studies have been carried out to indicate their beneficial effects. Medicinal properties of limonoids reported include antibacterial, antifungal, antimalarial, anticancer and antiviral activities $[6,7]$. In the last years, more than 100 limonoids have been isolated and characterized [8]. In our previous study, we reported the isolation and characterization of three limonoids compounds (dregeanin DM4, rohituka 3 and trichilia lactone D5) from Trichilia welwitschii C.DC. [9].

Trichilia welwitschii is a West African member of the Meliaceae growing as a large tree in the Terra Firma Forests of Nigeria, Cameroon, Angola and Gabon [10]. Species from the Meliaceae family and especially Trichilia genus have been well-documented for their ability to metabolize structurally diverse and biologically significant triterpenoids and limonoids [11]. No previous pharmacological study has been reported on compounds isolated from T. welwitschii. In our continue search of bioactive compounds from plants and owing to the wide range of pharmacological and therapeutic properties of limonoids, this study was carried out to investigate the potential antiproliferative, nitric oxide and acetylcholinesterase inhibitory activity of three limonoids isolated from T. welwitschii.

\section{Results and discussion Cytotoxicity study}

Our goal was to determine whether the limonoid compounds exerted an inhibitory effect on cancer cell proliferation and their safety toward normal Vero cells. Therefore cytotoxic effect was evaluated against THP-1 and RAW 264.7 cancer cell lines and Vero cells as control. Doxorubicin and puromycin were used as standard anticancer drug. Puromycin is an aminonucleoside antibiotic, derived from the Streptomyces alboniger bacterium and used in cell biology as selective agent in cell culture systems for its toxicity to prokaryotic and eukaryotic cells [12]. Doxorubicin is commonly used to treat some leukemias and Hodgkin's lymphoma, as well as cancers of the bladder, breast, stomach, lung, ovaries, thyroid, soft tissue sarcoma, multiple myeloma, and others [13]. The respective $\mathrm{LC}_{50}$ values and selectivity index (SI) are presented in Table 1. All the compounds had some level of toxicity which could be considered as weak or moderate cytotoxicity compared to puromycin and doxorubicin $\left(\mathrm{LC}_{50}\right.$ values of $1.15-5.32$ and $1.06-9.35 \mu \mathrm{g} / \mathrm{mL}$ respectively) used as reference cytotoxic compounds. The selectivity index (SI) values varied from 0.83 to 2.99 for limonoid compounds. The compounds were not toxic to Vero cells with $\mathrm{LC}_{50}$ values ranging from 89.17 to $75.82 \mu \mathrm{g} / \mathrm{mL}$. The $\mathrm{LC}_{50}$ values varied between 81.20 and $84.53 \mu \mathrm{g} / \mathrm{mL}$ on THP-1. No significant antiproliferative activity was noted against the cancer cells with the exception of compound (1) with $\mathrm{LC}_{50}$ value of $23.55 \mu \mathrm{g} / \mathrm{mL}$ on RAW 264.7 cells. These results suggested that compounds $\mathbf{2}$ and $\mathbf{3}$ are not useful as antiproliferative therapeutic agent, due to their high $\mathrm{IC}_{50}$ concentration against THP-1 and RAW 264.7 cells. However, the potential antiproliferative effects of trichilia lactone D5 (1) against RAW 264.7 cancer cells is in line with previous

Table 1 Cytotoxicity $\left(\mathrm{LC}_{50}\right.$ in $\mu \mathrm{g} / \mathrm{mL}$ ) and the selectivity index (SI) of three limonoids isolated from Trichilia welwitschii and reference compounds (doxorubicin and puromycin) against cancer cell lines

\begin{tabular}{|c|c|c|c|c|c|}
\hline \multirow[t]{2}{*}{ Compounds } & \multirow[t]{2}{*}{ Vero } & \multicolumn{2}{|l|}{ THP-1 } & \multicolumn{2}{|l|}{ RAW 264.7} \\
\hline & & $\mathrm{LC}_{50}$ & SI & $\mathrm{LC}_{50}$ & SI \\
\hline 1 & $89.17 \pm 5.00^{a}$ & $81.20 \pm 6.38^{a}$ & 0.87 & $23.55 \pm 5.77^{a}$ & 2.99 \\
\hline 2 & $85.22 \pm 6.31^{a}$ & $81.20 \pm 4.04^{a}$ & 0.87 & $65.68 \pm 3.64^{b}$ & 1.07 \\
\hline 3 & $75.82 \pm 1.85^{b}$ & $84.53 \pm 5.81^{a}$ & 0.83 & $61.86 \pm 4.14^{b}$ & 1.14 \\
\hline Doxorubicin & $9.35 \pm 0.66^{c}$ & nd & nd & $1.06 \pm 0.65^{c}$ & 66.42 \\
\hline Puromycin & $5.32 \pm 0.90^{d}$ & $0.4 \pm 0.02^{b}$ & 176.03 & $1.15 \pm 0.17^{c}$ & 61.23 \\
\hline
\end{tabular}

Values with different letters are significantly different at $\mathrm{p}<0.05$

nd not determined 
reports on the antiproliferative activity of limonoids compounds [14-16].

\section{NO inhibitory activity}

Macrophages produce inflammatory mediators including NO in response to bacterial LPS; NO plays a pivotal role in many body functions; however, its overproduction can lead to cytotoxicity and inflammation [17]. Therefore, NO inhibitors are essential for preventing inflammatory diseases. Nitric oxide plays an important role in the inflammatory process, and an inhibitor of $\mathrm{NO}$ production and may be considered as a potential antiinflammatory agent. Therefore, NO inhibitors are essential for preventing inflammatory diseases. Quercetin has been reported to significantly suppress NO production in LPS-stimulated RAW 264.7 murine macrophage cell line [18]. In this study, RAW 264.7 macrophages were treated with LPS and various concentrations of limonoid compounds and quercetin as control, then NO production and cell viability were measured. The limonoid compounds had a concentration dependent inhibition on $\mathrm{NO}$ production induced by lipopolysaccharide (LPS) in macrophages (Fig. 1a). At the lowest concentration $(0.5 \mu \mathrm{g} /$ $\mathrm{mL}$ ), compound (2) and (3) released the lowest amount nitric oxide ( 2.97 and $2.93 \mu \mathrm{M}$, respectively). The cytotoxicity of compounds against RAW 264.7 macrophages was also tested by MTT assay (Fig. 1b). Compound (1) had slight toxic effect; while the two other compounds did not had significant cytotoxicity at the concentration leading to effective inhibition of NO production. For the two other limonoids compounds, 2-hydroxyxylorumphiin $\mathrm{F}$ and xylorumphiin I have been described a moderate inhibitory activity against nitric oxide production from LPS-activated macrophages with $\mathrm{IC}_{50}$ values of 24.5 and $31.3 \mu \mathrm{M}$, respectively [19]. Additionally, for six limonoids including trichilinin B (1), 4, ohchinin (7), 23-hydroxyohchininolide (8), 21-hydroxyisoohchininolide (9), 10, and methyl indole 3-carboxylate (12), have been described and inhibited production of $\mathrm{NO}$ with $\mathrm{IC}_{50}$ values in the range of $4.6-87.3 \mu \mathrm{M}$ and with no toxicity to the cells [14]. Our results provided further examples of the importance of limonoid compounds as potential antiinflammatory agents targeting NO inhibition.

\section{Acetylcholinesterase inhibition}

Recognized factors in Alzheimer's disease include free radicals, inflammation of the brain tissue and acetylcholine deficiency. Therefore, acetylcholine breakdown in the brain can be prevented by the inhibition of acetyl cholinesterase activity, leading to an increase in acetylcholine concentration. In the present study, limonoid compounds were investigated for their ability to inhibit the activity of AChE comparatively to galantamine.

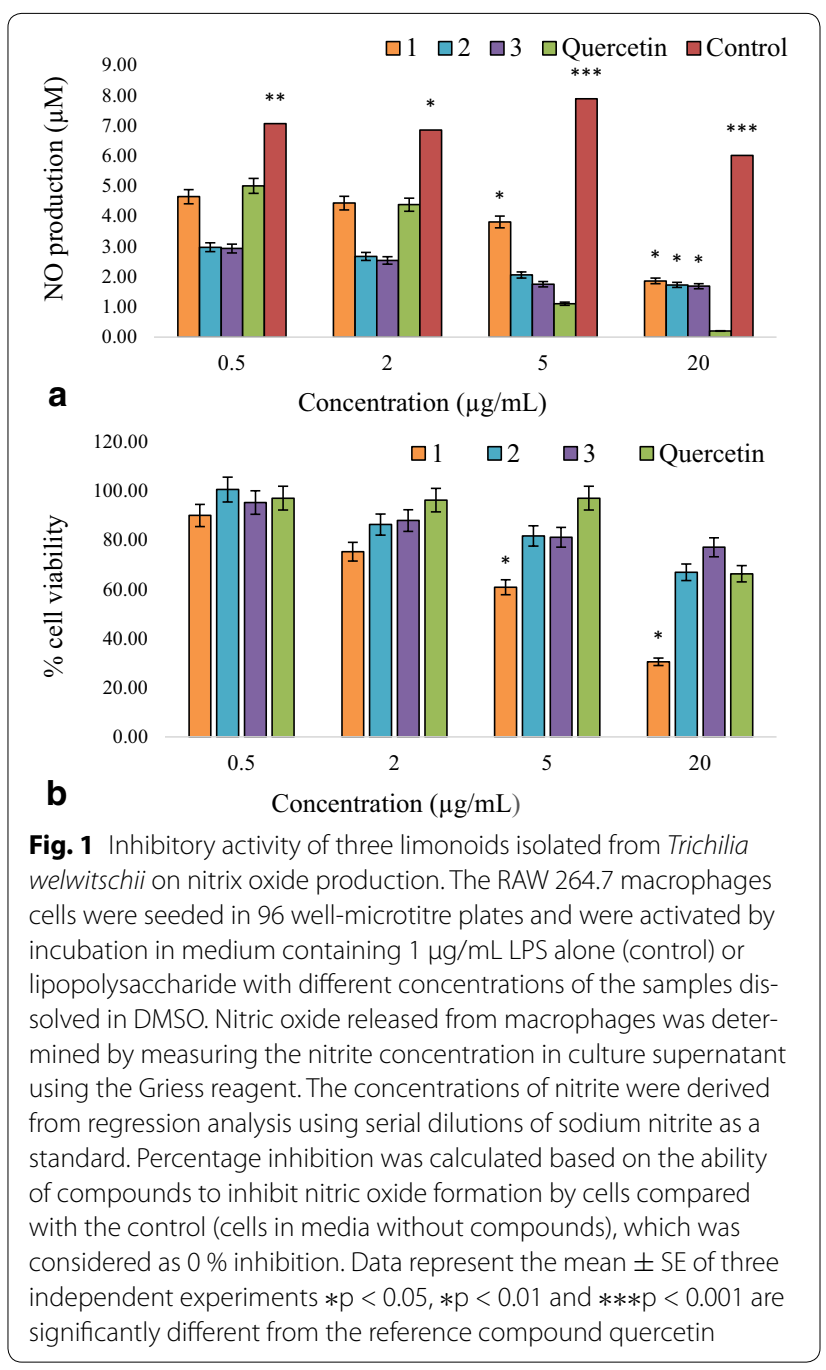

Results are presented in Table 2. Galantamine is a reversible cholinesterase inhibitor used for the treatment of mild to moderate Alzheimer's disease and various other memory impairments [20]. Compare to galantamine $\left(\mathrm{IC}_{50}\right.$ of $8.22 \mu \mathrm{g} / \mathrm{mL}$ ) used as standard AChE inhibitor; the three limonoids isolated from Trichilia welwitschii had weak to moderate inhibitory activities. At $50 \mu \mathrm{g} /$ $\mathrm{mL}$, the inhibitory potential of limonoids $\mathbf{1}, \mathbf{2}$ and $\mathbf{3}$ was 94.33, 82.67 and $87 \%$ respectively. At the lowest concentration $(6.25 \mu \mathrm{g} / \mathrm{mL})$, the AChE inhibitory activity of the three compounds dropped to $28.00,14.00$ and $30.33 \%$ for limonoids 1, 2 and 3 respectively. Concentration dependent inhibition was also observed and the $\mathrm{IC}_{50}$ values ranged from $19.13 \mu \mathrm{g} / \mathrm{mL}$ for compound (1) to $34.15 \mu \mathrm{g} /$ $\mathrm{mL}$ for compound (2) and $45.69 \mu \mathrm{g} / \mathrm{mL}$ for compound (3). However, all the samples had lower inhibitory activities compare with that of galantamine $\left(\mathrm{IC}_{50} 8.22 \mu \mathrm{g} / \mathrm{mL}\right)$. Not much work has been done on the AChE activity of Trichilia species [21]. There is a widespread effort to find 
Table 2 Acetylcholinesterase inhibitory activity of three limonoids isolated from Trichilia welwitschii and reference compound (galantamine)

\begin{tabular}{llll}
\hline Compounds & $\begin{array}{l}\text { Concentration } \\
(\boldsymbol{\mu} \mathbf{g} / \mathbf{m L})\end{array}$ & $\%$ AChE inhibition & $\mathbf{I C}_{\mathbf{5 0}}(\boldsymbol{\mu \mathbf { g }} / \mathbf{m L})$ \\
\hline $\mathbf{1}$ & 50 & $94.33 \pm 8.15$ & $19.13 \pm 0.41^{\mathrm{a}}$ \\
& 25 & $71.67 \pm 6.03$ & \\
12.5 & $18.00 \pm 8.89$ & \\
& 6.25 & $28.00 \pm 6.56$ & \\
$\mathbf{2}$ & 50 & $82.67 \pm 7.04$ & $34.15 \pm 1.66^{\mathrm{b}}$ \\
& 25 & $67.00 \pm 4.36$ & \\
& 12.5 & $47.33 \pm 2.08$ & \\
$\mathbf{3}$ & 6.25 & $14.00 \pm 6.00$ & \\
& 50 & $87.00 \pm 8.74$ & $45.69 \pm 3.65^{\mathrm{c}}$ \\
& 25 & $70.67 \pm 3.50$ & \\
& 12.5 & $31.67 \pm 5.20$ & \\
& 6.25 & $30.33 \pm 3.51$ & \\
& 20 & $83.00 \pm 8.89$ & $8.22 \pm 2.73^{\mathrm{d}}$ \\
& 5 & $69.67 \pm 4.16$ & \\
& 2 & $57.67 \pm 4.04$ & \\
& 0.5 & $38.00 \pm 1.00$ & \\
\hline
\end{tabular}

Values with different letters are significantly different at $p<0.05$

new AChE inhibitors from natural source, but not much work has focused on limonoid compounds. Our compounds had a much higher anti- AChE activity than the limonoids from Kigelia africana (Bignoniaceae) with $\mathrm{IC}_{50}$ values in the ranges $137.5-225.2 \mu \mathrm{M}$ [22].

\section{Conclusion}

The limonoid compounds studied in this work inhibited nitric oxide production in LPS-stimulated macrophages and presented AChE inhibitory activity. They had low cytotoxicity against Vero cells lines. The potential antiproliferative effect of compound against RAW 264.7 cancer cells was also demonstrated. This study provided further examples of the importance of limonoid compounds as potential AChE inhibitors and anti-inflammatory agents targeting the inhibition of NO production.

\section{Methods}

\section{Chemicals}

Sodium dodecyl sulphate, bovine serum albumin (BSA), sodium chloride $(\mathrm{NaCl}), \mathrm{MgCl}_{2} \cdot 6 \mathrm{H}_{2} \mathrm{O}$, acetylthiocholine iodide (ATCI), galantamine, 5,5-dithiobis-2-nitrobenzoic acid (DTNB), acetylcholinesterase (AChE) enzyme from electric eels (type VI-S lyophilized powder), sodium nitrite, ferrous sulfate, indomethacin and 15-lipoxygenase from Glycine max purchased from Sigma (Germany) and Tris(hydroxymethyl)aminomethane from Sigma, (Switzerland). Foetal calf serum (FCS), penicillin/ streptomycin/fungizone (PSF) and Dulbecco's modified Eagle's medium (DMEM) were obtained from Highveld Biological Products (South Africa). Phosphate buffered saline (PBS) and trypsin were purchased from Whitehead Scientific (South Africa). Quercetin, 3-(4,5-dimethylthiazol-2-yl)-2,5-diphenyl-tetrazolium bromide (MTT) were purchased from Sigma-Aldrich St. Louis, MO, USA.

\section{Limonoids compounds}

The three limonoids compounds (dregeanin DM4, rohituka 3 and trichilia lactone D5) studied in this work were isolated from seeds of Trichilia welwitschii. We previously described the isolation procedure and the structure elucidation of the compounds [9]. Chemical structures are shown in Fig. 2.

\section{Cytotoxicity}

\section{Cell culture}

Cells lines including human monocytic THP-1, murine macrophage RAW 264.7 and the Vero monkey kidney cell lines were obtained from the American Type Culture

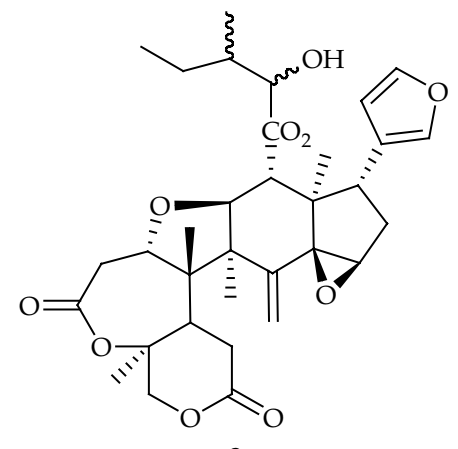

3

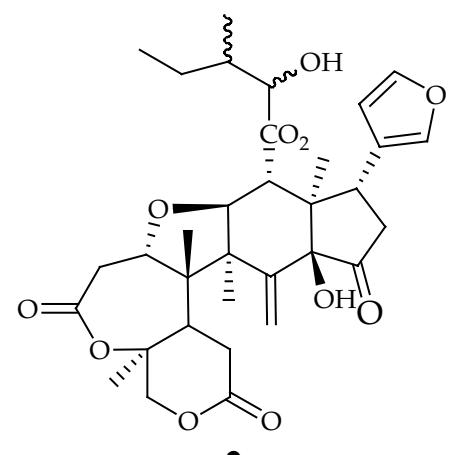

2

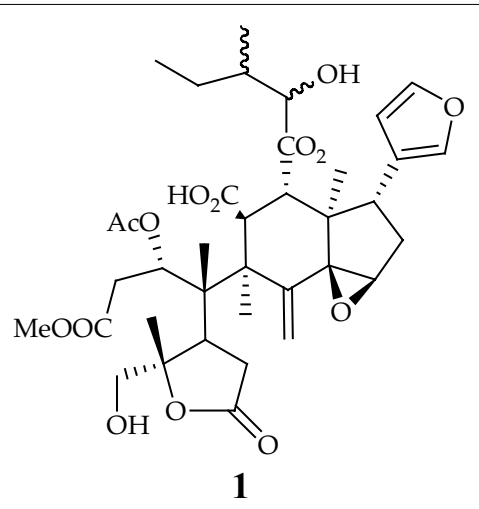

1

Fig. 2 Compounds isolated from T. welwitschii. 1 Trichilia lactone D5; 2 rohituka 3; 3 dregeanin. The isolation procedure and the structure elucidation of the compounds were previously described [9] 
Collection (Rockville, MD, USA). They were maintained in DMEM supplemented with $10 \%$ fetal calf serum (FCS) and $1 \%$ penicillin/streptomycin/fongizone (PSF) under standard cell culture conditions at $37{ }^{\circ} \mathrm{C}$ and $5 \% \mathrm{CO}_{2}$ in a humidified environment.

\section{MTT assay}

The cytotoxicity of compounds was determined by the 3-[4,5-dimethylthiazol-2-yl]-2,5-diphenyltetrazolium (MTT) assay as previously described [23]. The selectivity index (SI) values were calculated by dividing cytotoxicity $\mathrm{LC}_{50}$ values of normal Vero cells by the $\mathrm{LC}_{50}$ of cancer cells in the same units.

\section{Nitric oxide inhibitory activity and viability of LPS-activated RAW 264.7 macrophages}

The RAW 264.7 macrophages cells were seeded in 96 well-microtitre plates and were activated by incubation in medium containing $1 \mu \mathrm{g} / \mathrm{mL}$ LPS alone (control) or lipopolysaccharide with different concentrations of the samples dissolved in DMSO. Quercetin served as a positive control NO inhibitor for the reduction of NO production [18].

\section{Measurement of nitrite}

Nitric oxide released from macrophages was determined by measuring the nitrite concentration in culture supernatant using the Griess reagent. After $24 \mathrm{~h}$ incubation, $100 \mu \mathrm{L}$ of supernatant from each well of cell culture plates was transferred into 96-well microtitre plates and an equal volume of Griess reagent was added. The absorbance of the resultant solutions was determined on a BioTek Synergy microplate reader after $10 \mathrm{~min}$ at $550 \mathrm{~nm}$. The concentrations of nitrite were derived from regression analysis using serial dilutions of sodium nitrite as a standard. Percentage inhibition was calculated based on the ability of compounds to inhibit nitric oxide formation by cells compared with the control (cells in media without compounds), which was considered as $0 \%$ inhibition.

\section{Cell viability}

To determine whether the observed nitric oxide inhibition was not due to cytotoxic effects, MTT assay was also performed on the macrophage cells as previously described [23].

\section{Acetylcholinesterase inhibition activity}

Inhibition of acetylcholinesterase activity was determined using Ellman's colorimetric method [24] with slight modifications. In a 96-well plate was placed: $25 \mu \mathrm{L}$ of $15 \mathrm{mmol} / \mathrm{L}$ ATCI in water, $125 \mu \mathrm{L}$ of $3 \mathrm{mmol} / \mathrm{L}$ DTNB in Buffer A $(50 \mathrm{mmol} / \mathrm{L}$ Tris $-\mathrm{HCl}, \mathrm{pH} 8.0$, containing
$0.1 \mathrm{~mol} / \mathrm{L} \mathrm{NaCl}$ and $\left.0.02 \mathrm{~mol} / \mathrm{L} \mathrm{MgCl}_{2} \cdot 6 \mathrm{H}_{2} \mathrm{O}\right), 50 \mu \mathrm{L}$ of Buffer B $(50 \mathrm{mmol} / \mathrm{L}, \mathrm{pH} 8$, containing $0.1 \%$ bovine serum albumin) and $25 \mu \mathrm{L}$ of samples (serially diluted: $500-3.9 \mu \mathrm{g} / \mathrm{mL}$ for extract and fraction and 100-0.78 $\mu \mathrm{g} /$ $\mathrm{mL}$ for compounds and galantamine used as AChE standard inhibitor). Then, AChE $(0.2 \mathrm{U} / \mathrm{mL})$ was added to the wells and the absorbance was determined spectrophotometrically (BioTek Synergy microplate reader) at $405 \mathrm{~nm}$. Distilled water was used as negative control. The percentage of inhibition was calculated as follow:

$$
\begin{aligned}
& \mathrm{V}=\Delta_{\text {Abs }} / \Delta_{\mathrm{t}}, \\
& \% \text { enzyme activity }=\left(\mathrm{V} / \mathrm{V}_{\max }\right) \times 100, \\
& \% \text { enzyme inhibition }=100-\% \text { enzyme activity }
\end{aligned}
$$

where $\mathrm{V}$ is the rate of the reaction in the presence of inhibitor and $\mathrm{V}_{\max }$ is the reaction's rate of the control without inhibitor. The $\mathrm{IC}_{50}$ values of samples leading to $50 \%$ inhibition were calculated by plotting the percentage of inhibition against the concentrations.

\section{Statistical analysis}

All results are presented as means of triplicate experiments. All experiments were conducted in triplicate and values expressed as mean \pm standard deviation. Statistical analysis was performed with GraphPad InStat Software and results were compared using the StudentNewman Keul test at 5, 1 or $0.1 \%$ significance level.

\section{Abbreviations \\ NO: nitric oxide; AChE: acetylcholinesterase; ATCl: acetylthiocholine iodide; DTNB: 5,5-dithiobis-2-nitrobenzoic acid; DMEM: Dulbecco's modified Eagle's medium.}

\section{Authors' contributions}

JPD performed experiments and wrote the first draft of manuscript. ATT and RM isolated the compounds. PM and AENkengfack and supervised the chemistry part of the work. JNE and LJM supervised the biological part of work and revised the final manuscript. All authors read and approved the final manuscript.

\section{Author details}

1 Department of Paraclinical Sciences, Faculty of Veterinary Science, University of Pretoria, Private Bag X04, Onderstepoort, Pretoria 0110, South Africa.

${ }^{2}$ Department of Biochemistry, Faculty of Science, University of Dschang, P.O. Box 67, Dschang, Cameroon. ${ }^{3}$ Department of Organic Chemistry, Faculty of Science, University of Yaoundé I, P.O. Box 812, Yaoundé, Cameroon.

\section{Acknowledgements}

The University of Pretoria provided a postdoctoral fellowship to JPD. The National Research Foundation (NRF) and Medical Research Council (MRC) provided funding to support this study.

\section{Competing interests}

The authors declared that they have no competing interests.

Received: 13 July 2015 Accepted: 1 October 2015

Published online: 13 October 2015 


\section{References}

1. Hirai S, Horii S, Matsuzaki Y, Ono S, Shimmura Y, Sato K, Egashira Y. Antiinflammatory effect of pyroglutamyl-leucine on lipopolysaccharidestimulated RAW 264.7 macrophages. Life Sci. 2014;117(1):1-6.

2. Coussens LM, Werb Z. Inflammation and cancer. Nature. 2012;2012(420):860-7.

3. De Pablos RM, Espinosa-Oliva AM, Sarmiento M, Venero JL. Stress and inflammation: a detrimental combination in the development of neurodegenerative disease. Inflamm Cell Signal. 2014;1:e182.

4. Roy A, Saraf S. Limonoids: overview of significant bioactive triterpenes distributed in plants kingdom. Biol Pharm Bull. 2006;29:191-201.

5. Pekala J, Strub DJ, Koziol A, Lochynski S. Variability of Biological Activities of Limonoids Derived from Plant Sources. Mini-Rev Org Chem. 2015;11:269-79.

6. Miller EG, Porter JL, Binnie WH, Guo IY, Hasegawa S. Further studies on the anticancer activity of citrus limonoids. J Agric Food Chem. 2004;52:4908-12.

7. Champagne DE, Koul O, Isman MB, Scudder GGE, Towers GHN. Biological activity of limonoids from the rutales. Phytochemistry. 1992;31:377-94.

8. Tundis R, Loizzo MR, Menichini F. An overview on chemical aspects and potential health benefits of limonoids and their derivatives. Crit Rev Food Sci Nutr. 2014;54:225-50.

9. Tsamo A, Langat MK, Nkounga P, Waffo AFK, Nkengfack AE, Mulhollan DA. Limonoids from the West African Trichilia welwitschii (Meliaceae). Biochem Syst Ecol. 2013;50:368-70.

10. Louppe D, Oteng-Amoaka AA, Brink M. (Eds.), Plant resources of tropical Africa. Timbers 1. PROTA Foundation. Leiden: Blackhuys Publishers, 2008;7(1):562-3.

11. Curcino V, da Silva TW, dos Santos GM, Braz-Filho R. Secondary metabolites of the genus Trichilia: contribution to the chemistry of Meliaceae family. Am J Anal Chem. 2014;5:91-121.

12. Söderlund G, Haarhaus M, Chisalita S, Arnqvist HJ. Inhibition of puromycin-induced apoptosis in breast cancer cells by IGF-I occurs simultaneously with increased protein synthesis. Neoplasma. 2004;51(1):1-11.

13. Tacar O, Sriamornsak P, Dass CR. Doxorubicin: an update on anticancer molecular action, toxicity and novel drug delivery systems. J Pharm Pharmacol. 2013;65(2):157-70.

14. Pan X, Matsumoto M, Nishimoto Y, Ogihara E, Zhang J, Ukiya M, Tokuda H, Koike K, Akihisa M, Akihisa T. Cytotoxic and nitric oxide production-inhibitory activities of limonoids and other compounds from the leaves and bark of Melia azedarach. Chem Biodivers. 2014;11(8):1121-39.

15. Takagi M, Tachi Y, Zhang J, Shinozaki T, Ishii K, Kikuchi T, Ukiya M, Banno N, Tokuda H, Akihisa T. Cytotoxic and melanogenesis-inhibitory activities of limonoids from the leaves of Azadirachta indica (Neem). Chem Biodivers. 2014;11(3):451-68.

16. Kikuchi T, Ishii K, Noto T, Takahashi A, Tabata K, Suzuki T, Akihisa T. Cytotoxic and apoptosis-inducing activities of limonoids from the seeds of Azadirachta indica (neem). J Nat Prod. 2011;74(4):866-70.

17. Moncada S, Palmer RM, Higgs EA. Nitric oxide: physiology, pathophysiology, and pharmacology. Pharmacol Rev. 1991;43(2):109-42.

18. Mu MM, Chakravortty D, Sugiyama T, Koide N, Takahashi K, Mori I, Yoshida T, Yokochi T. The inhibitory action of quercetin on lipopolysaccharideinduced nitric oxide production in RAW 264.7 macrophage cells. J Endotoxin Res. 2001;7(6):431-8.

19. Sarigaputi C, Sommit D, Teerawatananond T, Pudhom K. Weakly antiinflammatory limonoids from the seeds of Xylocarpus rumphii. J Nat Prod. 2014;77(9):2037-43.

20. Samochocki M, Höffle A, Fehrenbacher A, Jostock R, Ludwig J, Christner C, Radina M, Zerlin M, Ullmer C, Pereira EF, Lübbert H, Albuquerque EX, Maelicke A. Galantamine is an allosterically potentiating ligand of neuronal nicotinic but not of muscarinic acetylcholine receptors. J Pharmacol Exp Ther. 2003;305(3):1024-36.

21. Amoo SO, Aremu AO, Moyo M, Van Staden J. Antioxidant and acetylcholinesterase-inhibitory properties of long-term stored medicinal plants. BMC Complement Altern Med. 2012;12:87.

22. Jabeen B, Riaz N, Saleem M, Naveed MA, Ahmed M, Tahir MN, Pescitelli G, Ashraf M, Ejaz SA, Ahmed I, Jabbar A. Isolation and characterization of limonoids from Kigelia Africana. Z Naturforsch. 2013;68b:1041-8.

23. Dzoyem JP, McGaw LJ, Eloff JN. In vitro antibacterial, antioxidant and cytotoxic activity of acetone leaf extracts of nine under-investigated Fabaceae tree species leads to potentially useful extracts in animal health and productivity. BMC Complement Altern Med. 2014;14:147.

24. Ellman GL, Courtney KD, Andres V Jr, Featherstone RM. A new and rapid colorimetric determination of acetylcholinesterase activity. Biochem Pharmacol. 1961;7:88-95.

\section{Submit your next manuscript to BioMed Central and take full advantage of:}

- Convenient online submission

- Thorough peer review

- No space constraints or color figure charges

- Immediate publication on acceptance

- Inclusion in PubMed, CAS, Scopus and Google Scholar

- Research which is freely available for redistribution

Submit your manuscript at 